\title{
SINGLE-NUCLEOTIDE POLYMORPHISMS OF CALCIUM-SENSING RECEPTOR ENCODING GENE ASSOCIATED WITH CALCIUM KIDNEY STONE DISEASE IN BABYLON PROVINCE
}

\author{
ZAHRAA ISAM ${ }^{1}$, RABAB OMRAN ${ }^{2 *}$, AMMAD HASSAN MAHMOOD \\ ${ }^{1}$ Department of Biology, College of Science, University of Babylon, Al-Hillah City, Babel, Iraq. ${ }^{2}$ Department of Biotechnology, Genetic \\ Engineering, College of Science, University of Babylon, Al-Hillah City, Babel, Iraq. ${ }^{3}$ Department of Urology, College of Medicine, University \\ of Babylon, Consultant urologist in Al-Hillah Teaching Hospital, Al-Hillah City, Babel, Iraq. Email: omranaljelawi@gmail.com
}

Received: 17 August 2017, Revised and Accepted: 10 October 2017

ABSTRACT

Objective: The calcium-sensing receptor (CASR) is a G-protein-coupled receptor that is mainly expressed in the parathyroid and the kidneys where it regulates parathyroid hormone secretion and renal tubular calcium reabsorption. Inactivating and activating $C A S R$ gene due to mutations severally caused hypercalcemia or hypocalcemia disorders. The aim of the study was to investigate the risk factor of $C A S R$ rs1801725 (Ala986Ser) patients with renal disease.

Method: The blood samples were collected from 100 patients and divided into two groups, each one containing 50 samples; chronic kidney disease and end-stage renal disease, who admitted Merjan Teaching Hospital in Babylon Province, Iraq, from February to July 2016. In addition, healthy persons as a control group (50 samples). Genotyping of CASR single-nucleotide polymorphisms (SNP) was performed using a polymerase chain reaction technique, followed by single-strand conformation polymorphism. Accordingly, these DNA polymorphisms were confirmed using DNA sequencing.

Results: The conformational haplotypes of CASR, exon7 NCBI Primer3plus reference were obtained in three patterns, including two, three, and four bands, due to the presence SNPs within the studied region. These SNPs leads to change three amino acid residues of CASR, including amino acid substitutions were Ala 128 $\rightarrow$ Ser 128, Leu 155 $\rightarrow$ Tye 155, and Leu 156 $\rightarrow$ Ser 156 that may affect or modified the tertiary structure of the receptor, subsequently the function like the affinity to calcium ion may be effected.

Conclusion: These results suggest that the variants of CASR SNP, namely, rs1801725 might be involved in susceptibility to kidney stone disease.

Keywords: Chronic and end-stage renal disease, Polymerase chain reaction, rs1801725, Calcium-sensing receptor, Single-nucleotide polymorphisms. (C) 2018 The Authors. Published by Innovare Academic Sciences Pvt Ltd. This is an open access article under the CC BY license (http://creativecommons. org/licenses/by/4. 0/) DOI: http://dx.doi.org/10.22159/ajpcr.2018.v11i2.22064

\section{INTRODUCTION}

Kidney stone could be formed a hard crystal accumulation from nutritional minerals within the kidneys when minerals in urine are in high concentration. The stones are typically aching related to hematuria and harm to kidney tissue and may be developed a renal failure [1]. The formation of most kidney stones is a multifactorial illness resulting from the mutual effect of epidemiologic, organic chemistry, environmental, and hereditary risk factors [2]. Threat factors include high urine calcium levels, calcium supplements, certain foods, obesity, hyperparathyroidism, gout, some medications, and not drinking enough fluids. The calcium-sensing receptor (CASR) is a member of Class C or III that associated with G-protein-coupled receptor. It is chiefly expressed in the parathyroid gland and the renal tubules of the kidney. It has a potential role to sense the change in the extracellular levels of calcium ion in these two organs. It regulates the parathyroid hormone (PTH) secretion and reabsorption of the calcium ion to control calcium homeostasis. In the kidney, it is synthesized in all nephron segments and it has an inhibitory effect on the reabsorption of calcium, sodium, potassium, and water depending on which segment of the tubule is being activated $[3,4]$. In accordance with this, mutations in the CASR gene issue have been shown to cause abnormalities in blood calcium (Ca levels). The presence of associative activating and inactivating mutation of CASR issue causes body dominant symptoms or familial hypocalciuric symptom severally [2,5]. The existence of an activating and alteration of gene casr causes dominant hypocalcemia or hypocalciuric familial hypercalcemia severally [5]. Three singlenucleotide polymorphisms (SNPS) inflicting non-conservative alterations of amino acid have been delineated on coding region (exon-7) of CASR. The foremost SNPS communal change of alanine to serine at region 986 is related to the inflated concentration of serum calcium and reduced calcium elimination [6]. Alternative two common SNPS (Arg990gly and Gln1011glu) assembled with Ala986ser. Later, reminder revisions between totally diverse polymorphisms of CASR and metallic element urinary are debatable, leading to positive $[5,7,8]$ or negative findings [9].

Several studies investigated the association between the CASR polymorphism and kidney stone disease (KSD); however, the results were conflicting. Some studies detected the presence of the high association between CASR polymorphism and KSD [10], whereas the others were not a big risk for KSD [11,12].

The differences of results in previous studies due to numerous factors including the disease etiology, civilization, variations in characteristic population, together with an interface with environmental factors, choice of management cluster, sample size, hereditary, also gene-gene and geneenvironment interactions [13]. The aim of this study was to analyze SNPs as a risk considered CASR region and connected with KSD in Iraqi patients.

\section{METHODS}

Sampling

This was a case study conducted between February and July 2016 in the Biotechnology and Genetic Engineering Laboratory, Department of Biology, College of Science, University of Babylon, Iraq. The blood samples (150) were collected from three groups, each one containing 50 subjects, including patients suffering from chronic kidney disease (CKD), end-stage renal disease (ESRD), and healthy persons as a control group. Blood samples were taken from out and in patients 
who admitted to Merjan Teaching Hospital (Dialysis Center), Babylon Province. All the participants were evaluated by a certified physician, who was also responsible for getting the most analytical and clinical values. The patients with hepatitis were excluded.

Genotypic identification using single-strand conformation polymorphism (SSCP)-polymerase chain reaction (PCR) amplification

The genotyping of the study groups was performed using the SSCPPCR technique after DNA extraction from blood samples. DNA of blood was extracted and purified using extraction and purification kit from Geneaid company (UK).

The targeted sites of DNA were amplified using design specific primers which used to identify CASR (rs1801725), obtained from Bioneer, IDT DNA (USA). Forward primer: 5'-AGCCCAGATGCAAGCAGAAG-3', and reverse primer: 5'- CAGACCTGTTTCCTGGACGG-3'.

PCR was carried out in $20 \mu \mathrm{l}$ reaction volumes containing $1 \mu \mathrm{l}$ from each forward and reverse primer, $12.5 \mu \mathrm{l}$ of Green Master Mix, 3 $\mu \mathrm{l}$ of Genomic DNA, and the reaction volume was completed up to $20 \mu \mathrm{l}$ by adding $2.5 \mu \mathrm{l}$ of the nuclease-free water. Amplification was carried out in a thermocycler (Biometra, Germany) programmed as pre-denaturation for $2 \mathrm{~min}$ at $94^{\circ} \mathrm{C} ; 30$ cycles, each cycle the denaturation for $5 \mathrm{~min}$ at $94^{\circ} \mathrm{C}$, annealing $1 \mathrm{~min}$ at $64^{\circ} \mathrm{C}$, extending for $1 \mathrm{~min}$ at $72^{\circ} \mathrm{C}$; and a final extension of $5 \mathrm{~min}$. PCR products were electrophoresed using gel electrophoresis (cleaver scientific - UK) in $1 \%$ agarose at $75 \mathrm{~V}$ for one hand visualized by ethidium bromide. Photos were taken using gel documentation system) Cleaver Scientific-UK).

The sharp and obvious bands were found after performing electrophoresis regarding exon7 of the CASR PCR fragment. These amplified fragments are subsequently suitable for downstream SSCP tests.

All the obtained SSCP gels were aligned with each other to show how many haplotypes were, two types of SSCP band patterns were observed in SSCP gels. The single-stranded (ssDNA) DNA bands, which occupy the upper portion of the gel and the double-stranded (dsDNA), which occupies the lower portion of the gel was observed. The variation of ssDNA in SSCP gels is relied on to identify the genetic pattern of each amplicon, and the condition for SSCP-PCR was $8 \%$ polyacrylamide gel electrophoresis power applied $75 \mathrm{~V}, 20 \mathrm{~mA}$ for $160 \mathrm{~min}$. After that gels visualized by ethidium bromide. Photos were taken using gel documentation system (EBOXCX - UK). The patterns of each SNPs that revealed by sequencing technique.

Statistical analysis

All the statistical analyses were done with the SPSS statistical software (version 17.0; SPSS Inc., Chicago, IL), $\mathrm{p}<0.05$ was considered statistically significant.

\section{RESULTS}

The DNA was extracted from the blood sample as a first step to isolate the genomic DNA of patients and healthy control. The Fig. 1 revealed the gel electrophoresis of genomic DNA ( $1 \%$ agarose, $75 \mathrm{~V}, 20 \mathrm{~mA}$ for $1 \mathrm{~h}$ ).

For CASR genotyping using the RCR-SSCP method, the genomic DNA of renal patients and healthy control groups was amplified using specific primers, which were designed according to the exon7 region of $C A S R$ of Homo sapiens reference ID: DQ327728.1 (https://www.ncbi.nlm.nih. gov/nuccore/DQ327728.1).

The genomic DNA amplification was accomplished by the thermocycler apparatus under the optimal conditions. The results revealed that the presence a single band (221bp) of the target sequence of an exon 7 region of CASR in agarose gel (Fig. 2), which contains a risk region (rs rs1801725).
After the amplification of the target site, conformational polymorphism of the exon7 region of the CASR gene using the PCR-SSCP method. All the obtained SSCP gels were aligned with each other to show how many haplotypes obtained. The results revealed the presence of the three haplotypes of SSCP band patterns were observed in SSCP gels. The single-stranded (ssDNA) DNA bands, which occupy the upper portion of the gel and the dsDNA, which occupies the lower portion of the gel was observed. The variation of ssDNA in SSCP gels is relied on to identify the genetic pattern of each amplicon, as shown in Fig. 3.

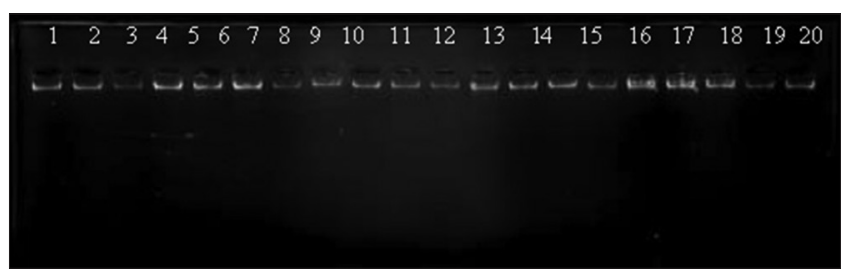

Fig. 1: Agarose gel electrophoresis pattern of genomic DNA extracted from the blood of renal patients and healthy control groups. Lane 1-20 refers to genomic DNA from blood samples; electrophoresis conditions, $1 \%$ agarose, $75 \mathrm{~V}, 20 \mathrm{~mA}$ for $1 \mathrm{~h}(10 \mu \mathrm{l}$ in each well)

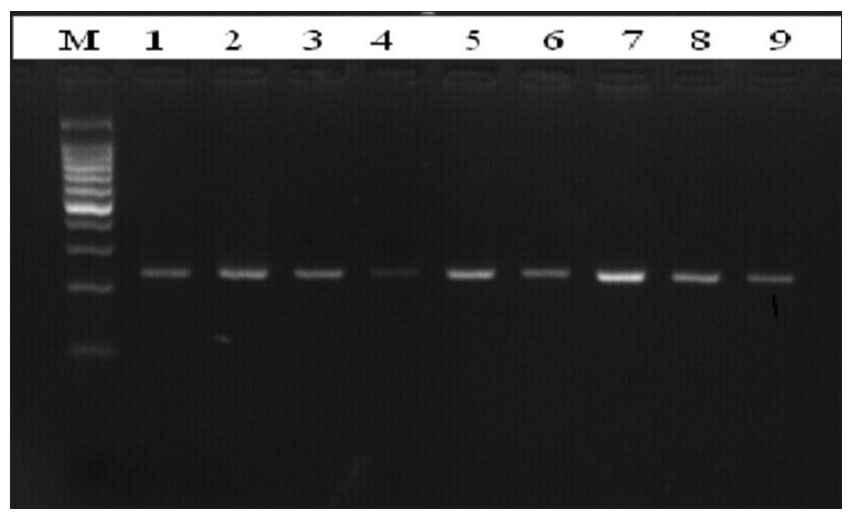

Fig. 2: Agarose gel electrophoresis of $C A S R$ amplification products of renal patients and healthy control groups. M; refers to DNA size marker lane 1-lane 9 refers to calcium-sensing receptor -polymerase chain reaction fragment patterns (221 bp). Electrophoresis conditions: 1\% agarose gel, $75 \mathrm{~V}, 20 \mathrm{~mA}$ for $120 \mathrm{~min}$. Staining method; precast ethidium bromide
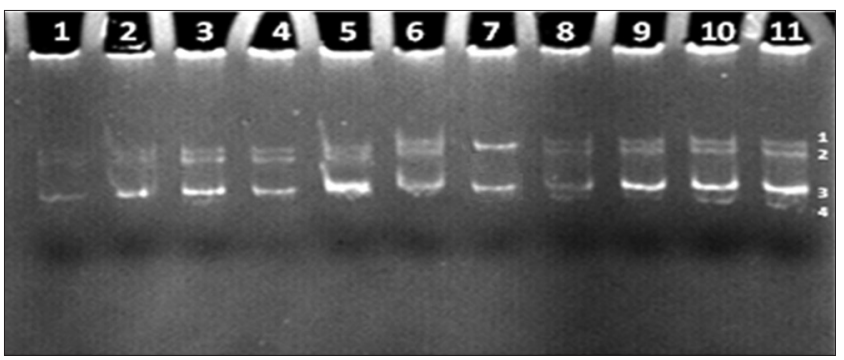

Fig. 3: DNA polymorphisms of the exon7 region of CASR gene, according to the number of the band using the polymerase chain reaction-single-strand conformation polymorphism (PCR-SSCP) technique. Lanes 1-10 refer to the target site within exon7 of the CASR gene PCR-SSCP haplotype patterns. Lanes 1 and 2 refer to 3-bands haplotype (homozygous) of healthy control management. Lanes 3-6 and 9 refer to 3-bands haplotype (homozygous) of patient groups; Lane 7 refers to 2-bands haplotype (homozygous) of patient groups; Lanes 8, 10, and 11 refer to 4-bands haplotype (heterozygous) of patient groups 
Electrophoresis conditions: 8\% polyacrylamide gel concentration; $200 \mathrm{~V}(7.5 \mathrm{~V} / \mathrm{cm})-100 \mathrm{~mA}$, time to run: $90-120 \mathrm{~min}$. Staining method; ethidium bromide.

The results of SSCP gel showed that the presence of different conformational DNA polymorphisms according to the number of the bands constitutes two (homozygous), three bands (homozygous), and four bands (heterozygous) (Fig. 3)

The results showed that conformational polymorphism distributions among the haplotypes were homozygous (2-bands) 38\%, homozygous (3-bands) 50\%, and heterozygous (4-bands) 12\%, respectively, in CKD group. Whereas, conformational haplotypes in ESRD group were homozygous (2-bands) 28\%, homozygous $60 \%$, and heterozygous (4-bands) $12 \%$, respectively, in comparison with the healthy control group was $18 \%$ homozygous, $62 \%$ homozygous (3-bands), and $20 \%$ heterozygous (4-bands), respectively. The results demonstrate that there is an association between DNA polymorphisms according to the number of bands with patients as compared with the control groups, as shown in Tables 1 and 2.
Table 3 summarizes to the present significant differences $(\mathrm{p} \leq 0.05)$ in the serum levels of urea, creatinine, and calcium among 2,3 , and 4 bands for the CASR gene in end-stage renal disease groups, while there are no significant differences in the concentrations of calcium, creatinine, and urea between 2, 3, and 4 bands of the CASR gene in CKD groups.

However, it might be difficult to determine the pattern of all resolved SSCP bands using only the gel visualization. Accordingly, these DNA polymorphisms must be confirmed using sequencing. The sequencing results observed that many SNPs between the one resolved haplotypes and between the CASR, exon7 for Primer3plus reference sequences. The results appeared in the presence of two SNPs (Fig. 4) which revealed that which located at position $81(\mathrm{C} / \mathrm{T})$ as a substitution mutation and the second was a deletion mutation (T) at the location 163 according to the reference sequence alignment of the human CASR gene ID: DQ327728.1 (https://www.ncbi.nlm.nih.gov/nuccore/DQ327728.1).

When translating the DNA sequence using by BioEdit program version 7.2.5, according to the reference sequence alignment of the

Table 1: Conformational haplotype polymorphism distribution of CASR gene by the number of bands and their association with CKD and control groups

\begin{tabular}{|c|c|c|c|c|c|}
\hline \multirow[t]{2}{*}{ Conformational haplotype polymorphism } & \multicolumn{2}{|l|}{ n (\%) } & \multirow[t]{2}{*}{$\mathrm{p}$ value } & \multirow[t]{2}{*}{ OR } & \multirow[t]{2}{*}{$95 \% \mathrm{CI}$} \\
\hline & CKD group & Control group & & & \\
\hline Homozygous 2-bandsa & $19(38)$ & $9(18)$ & 0.037 & 2.61 & $1.01-6.78$ \\
\hline Homozygous 3-bands & $25(50)$ & $31(62)$ & & & \\
\hline Heterozygous 4-bands & $6(12)$ & $10(20)$ & 0.05 & 3.51 & $0.97-12.72$ \\
\hline 3 -bands ${ }^{\mathrm{a}}$ & $25(50)$ & $31(62)$ & 0.41 & 1.34 & $0.42-4.20$ \\
\hline 4-bands & $6(12)$ & $10(20)$ & & & \\
\hline Total number & 50 & 50 & & & \\
\hline
\end{tabular}

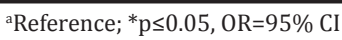

Table 2: Conformational haplotype polymorphism distribution of CASR gene by the number of bands and their association with end-stage renal disease and control groups

\begin{tabular}{|c|c|c|c|c|c|}
\hline \multirow[t]{2}{*}{ Conformational haplotype polymorphism } & \multicolumn{2}{|l|}{ n (\%) } & \multirow[t]{2}{*}{ p value } & \multirow[t]{2}{*}{ OR } & \multirow[t]{2}{*}{$95 \% \mathrm{CI}$} \\
\hline & ESRD group & Control group & & & \\
\hline Homozygous 2-bands ${ }^{a}$ & $14(28)$ & $9(18)$ & 0.23 & 1.60 & $0.60-4.26$ \\
\hline Heterozygous 4-bands & $6(12)$ & $10(20)$ & 0.13 & 3.88 & $0.69-9.64$ \\
\hline 3 -bands $\mathrm{s}^{\mathrm{a}}$ & $30(60)$ & $31(62)$ & 0.56 & 1.62 & $0.52-4.99$ \\
\hline 4-bands & $6(12)$ & $10(20)$ & & & \\
\hline Total number & 50 & 50 & & & \\
\hline
\end{tabular}

${ }^{a}$ Reference; $* \mathrm{p} \leq 0.05 ; \mathrm{OR}=95 \% \mathrm{CI}$

Table 3: The association of PCR-SSCP polymorphisms of CASR gene in renal disease groups with physiological parameter

\begin{tabular}{|c|c|c|c|}
\hline \multirow{2}{*}{$\begin{array}{l}\text { PCR-SSCP haplotypes } \\
\text { band (n) }\end{array}$} & \multicolumn{3}{|l|}{ Mean \pm SE } \\
\hline & Urea (mg/dl) & Creatinine $(\mu \mathrm{mol} / \mathrm{l})$ & Calcium (mmol/l) \\
\hline \multicolumn{4}{|l|}{ ESRD } \\
\hline Homozygous & $27.33 \pm 1.96$ & $427.35 \pm 7.07$ & $1.90 \pm 0.082$ \\
\hline \multicolumn{4}{|l|}{ 2-bands $(n=14)$} \\
\hline Homozygous & $24.64 \pm 1.20$ & $448.4 \pm 12.44$ & $1.853 \pm 0.091$ \\
\hline \multicolumn{4}{|l|}{ 3-bands $(n=30)$} \\
\hline Heterozygous 4-bands $(n=6)$ & $17.48 \pm 2.69$ & $428.0 \pm 12.76$ & $1.85 \pm 0.07$ \\
\hline $\mathrm{p}$ value & $0.018^{*}$ & 0.44 & 0.92 \\
\hline \multicolumn{4}{|l|}{ CKD } \\
\hline Homozygous & $25.96 \pm 1.66$ & $438.15 \pm 9.86$ & $2.24 \pm 0.17$ \\
\hline \multicolumn{4}{|l|}{2 -bands $(\mathrm{n}=19)$} \\
\hline Homozygous & $26.51 \pm 1.58$ & 428. $2 \pm 5.22$ & $2.17 \pm 0.08$ \\
\hline \multicolumn{4}{|l|}{3 -bands $(n=25)$} \\
\hline Heterozygous 4-bands $(\mathrm{n}=6)$ & $26.18 \pm 0.46$ & $456.16 \pm 13.01$ & $2.16 \pm 0.20$ \\
\hline $\mathrm{p}$ value & 0.96 & 0.18 & 0.88 \\
\hline
\end{tabular}

n: Patient number, CKD: Chronic kidney disease, ESRD: End-stage renal disease, $P \leq 0.05$, the results represent as mean \pm SE, SE: Standard error 


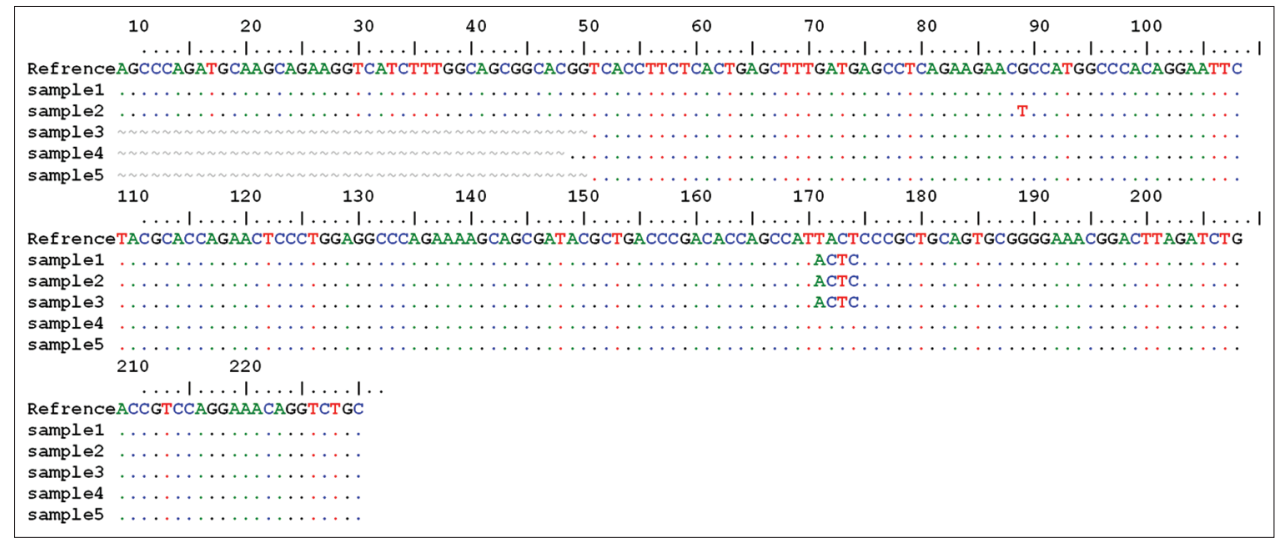

Fig. 4: Sequences alignment ID: DQ327728.1 results for Homo sapiens CASR gene fragment by BioEdit program version 7.2.5

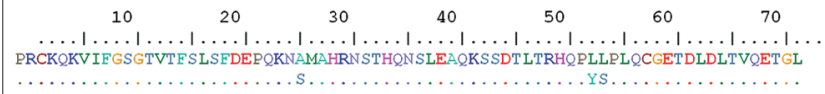

Fig. 5: Pair sequence alignment of the amino acid draw based on sequence alignment by BioEdit program version 7.2.5

human CASR gene ID: DQ327728.1. The results appeared change three amino acid residues of CASR protein as shown in Figs. 5 and 6. These amino acid substitutions were Ala $128 \rightarrow$ Ser 128 , Leu $155 \rightarrow$ Tye 155 , and Leu $156 \rightarrow$ Ser 156 that may affect or modified the tertiary structure of the receptor; subsequently, the function like the affinity to calcium ion may be effected or inhibit reabsorption on tubular calcium and PTH excretion (Fig. 6).

\section{DISCUSSION}

KSD could be a communal and a complicated impressive clinical circumstance an outsized load on economic the healthcare systems. Hypercalciuria is the main danger issue for the progress of a stone containing calcium. A change of kidney systems of calcium eliminations is the foremost cause for hypercalciuria. The G-protein-coupled CASR as a receptor is expressed within the cell basolateral shows essential roles within the directive secretion of PTH and excretory organ cannular Ca biological process in reaction to Ca blood levels [14]. The CASR reduction calcium reabsorption renal tubules and hypercalciuria caused by defeating the action of calcium potassium subtle channels. The gene encoding CASR is additionally controlled by $V D R$, and raise levels of $V D R$ are determined in hypercalciuric genetic variation forming stone rats are involved within the multiplied urinary organ CASR informational RNA induced by one, 25 dihydroxy aliment D3 [15]. The mutation of CASR factor an activating and inactivating source chromosome main hypocalcemia or family hypocalciuric symptom severally; three SNPs inflicting non-conservative amino acid changes are defined on exon7, encoding the CASR. The foremost SNPs mutual, replacement of amino acid to an amino acid at sequence 986 is related to raise liquid body substance $\mathrm{Ca}$ concentration and reduced $\mathrm{Ca}$ excretion [5].

Other studies reported the CLDN14 play an essential role within the directive of excretory organ Ca excretion. CLDN14 is additionally controlled by signaling CASR. Expression of CLDN14 would be amplified by the mutation activating of CASR gene and triggering nephrocalcinosis [16]. Consequently, these three genes (VDR, CASR, and CLDN14) are reflected as a gene contestant for KSD and may be present an association of $V D R, C A S R$, and $C L D N 14$ genes in person with KSD in of India the eastern part.

In an alternative study, three polymorphisms are known within the CASR: Ala986Ser, Arg990Gly, and Glu1011Gln. Ala986Ser was the foremost variant polymorphic frequent in many inhabitants. Furthermore, the researcher had a tendency to create that $986 \mathrm{Ser}(\mathrm{T})$ factor is considerably related to KSD [17]. The diversity of revisions association between 986Ser (T) allele and higher levels of serum calcium has observed. In covenant with the conclusions from the other readings, they also found the significantly higher level of calcium concentrations were in individuals carrying 986Ser

(T) allele in our study. This finding suggests the activity of CASR inhibit reabsorption on tubular calcium and PTH excretion be dejected in carrying 986Ser (T) allele subjects. Sensitive of CASR to serum calcium for its site on the tubular cell basolateral membrane. Here, CASR moderates reabsorption of calcium conferring to the calcium serum levels [7].

Other necessary of CASR gene polymorphism is Arg990Gly placed in coding region exon7 and related to hypercalciuria to persons with and will not kidney stones. In vitro analysis consequences showed that the Arg990Gly variation will produce to again purposeful for the CASR [7]. Consequently, the 990Gly factor will increase the sensitivity of CASR, which should consequence in the superior reticence reabsorption of calcium into the cells of the Henle's loop that caused high levels of calcium excretion [18]. A great Ca levels of excretion area unit prospectively hazardous for the renal because it improves the chance of inorganic precipitation of phosphate within the kidney and created stones.

Finally, the change of some amino residues of receptor protein due to SNPs formation in exons of the encoding gene may change or modulate the function of receptor or dysregulation of the homeostasis of ions in tissues or blood. These results resemble the structural modulation of other proteins, particularly the receptors which leads to modulation or dysregulation of receptors through an increase in polar residues donated to surface interaction. The occurrence of polar residues rises the Van der Waals force, which could be the donating factor to increase in free energy and thereby to reduce the stability. The SNP incidence interferes with the overall conformation of the complex and could affect the regulation of the cytosolic part of the receptor and thereby influencing its function or affects on protein stability $[19,20]$.

\section{CONCLUSION}

These results suggest that the variants of CASR SNP, namely, rs1801725 might be involved in susceptibility to KSD.

\section{ACKNOWLEDGMENT}

The authors are thankful to College of Science, Babylon University, and Dialysis unit at Morgan Hospital in Babylon Province, and the faculties for providing facilities needed for our work. We appreciate the agreements of patients and cooperation to provide the blood samples. 


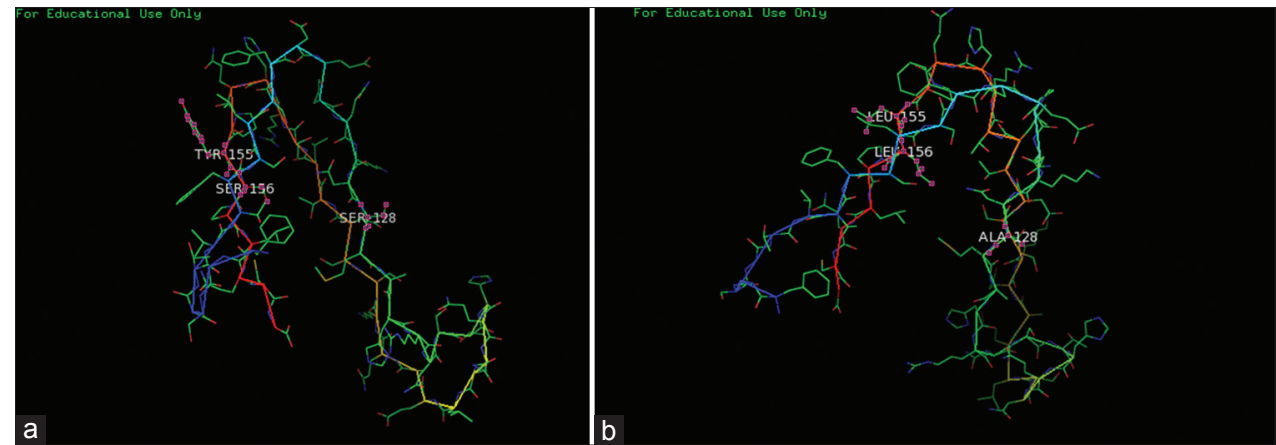

Fig. 6: Substitution of amino acids of CASR gene (a) normal 3D of secondary structure ribbon model, (b) abnormal 3D of secondary structure ribbon model

\section{REFERENCES}

1. Guha M, Bankura B, Ghosh S, Pattanayak AK, Ghosh S, Pal DK, et al. Polymorphisms in CaSR and CLDN14 genes associated with increased risk of kidney stone disease in patients from the Eastern Part of India. PLoS One 2015;10:e130790.

2. Devuyst O, Pirson Y. Genetics of hypercalciuric stone forming diseases. Kidney Int 2007;72:1065-72.

3. Brown EM, Hebert SC. A cloned $\mathrm{Ca}^{2+}$ sensing receptor: A mediator of direct effects of extracellular $\mathrm{Ca}^{2+}$ on renal function. J Am Soc Nephrol 1995;6:1530-40

4. Brown EM, Hebert SC. Calcium receptor regulated parathyroid and renal function. Bone 1997;20:303-9.

5. Scillitani A, Guarnieri V, Battista C, De Geronimo S, Muscarella LA, Chiodini I, et al. Primary hyperparathyroidism and the presence of kidney stones are associated with different haplotypes of the calciumsensing receptor. J Clin Endocrinol Metab 2007;92:277-83.

6. Cole DE, Peltekova VD, Rubin LA, Hawker GA, Virth R, Liew CC, et al. A986S polymorphism of the calciumsensing receptor and circulating calcium concentrations. Lancet 1998;353:112-5.

7. Vezzoli G, Terranegra A, Arcidiacono T, Biasion R, Coviello D, Syren ML, et al. R990G polymorphism of calciumsensing receptor does produce gainoffunctionand predispose to primary hypercalciuria. Kidney Int 2007:71:1155-62.

8. Hamilton DC, Grover VK, Smith CA, Cole DE. Heterogeneous disease modeling for hardy-weinberg disequilibrium in case-control studies: Application to renal stones and calciumsensing receptor polymorphisms. Ann Hum Genetics 2009;73:176-83.

9. Harding B, Curley AJ, Hannan FM, Christie PT, Bowl MR, Turner JJ, et al. Functional characterization of calciumsensing receptor polymorphisms and absence of association with indices of calcium homeostasis and bone mineral density. Clin Endocrinol 2006;65:598-5.

10. Seyhan S, Yavascaoglu I, Kilicarslan H, Dogan HS, Kordan Y. Association of vitamin D receptor gene Taq I polymorphism with recurrent urolithiasis in children. Int J Urol 2007;14:1060-2.

11. Heilberg IP, Goldfarb DS. Optimum nutrition for kidney stone disease.
Adv Chronic Kidney Dis 2013;20:165-74.

12. Vezzoli G, Terranegra A, Soldati L. Calciumsensing receptor gene polymorphisms in patients with calcium nephrolithiasis. Curr Opin Nephrol Hypertens 2012;21:355-61.

13. Gunes S, Bilen CY, Kara N, Asci R, Bagci H, Yilmaz AF. Vitamin D receptor gene polymorphisms in patients with urolithiasis. Urol Res 2006;34:47-52.

14. Ferreira LG, Pereira AC, Heilberg IP. Vitamin D receptor and calciumsensing receptor gene polymorphisms in hypercalciuric stoneforming patients. Nephron Clin Pract 2009;114:135-44.

15. Yao JJ, Bai S, Karnauskas AJ, Bushinsky DA, Favus MJ. Regulation of renal calcium receptor gene expression by 1,25 dihydroxyvitamin D3 in genetic hypercalciuricstoneforming rats. J Am Soc Nephrol 2005;16:1300-8

16. Dimke H, Desai P, Borovac J, Lau A, Pan W, Alexander RT. Activation of the $\mathrm{Ca}^{2+}$ sensing receptor increases renal claudin14 expression and urinary $\mathrm{Ca}^{2+}$ excretion. Am J Physiol Renal Physiol 2013;304:F761-9.

17. O'Seaghdha CM, Yang Q, Glazer NL, Leak TS, Dehghan A, Smith AV, et al. Common variants in the calciumsensing receptor gene are associated with total serum calcium levels. Hum Mol Genet 2010;19:4296-303.

18. Gambaro G, Soldati L, Vezzoli G. Genetics and molecular biology of renal stones. In: Rao PN, Preminger GM, Kavanagh JP, editors. Urinary Tract Stone Disease. London: Springer-Verlag London Limited.; 2011. p. 9-15.

19. Thiyagara A, Sunny JS, Hopper W. Effect of toll-like receptor inhibitor imiquimod on IL1R1 interaction with IL-1RA and ITS variant-an in silico approach. Int J Pharm Pharm Sci 2016;8:109-12.

20. Murthy VB, Chowdary M, Sucharitha I. In silico prediction of deleterious and non-deleterious nsSNPs in CFTR gene variants. Int J Pharm Pharm Sci 2016;8:303-6. 